\title{
Composition and microbiological quality of raw milk refrigerated in community
}

\section{tanks}

\section{Composição e qualidade microbiológica do leite cru refrigerado em tanques comunitários \\ Composición y calidad microbiológica de la leche cruda refrigerada en tanques comunitarios}

Cleube Andrade Boari

ORCID: https://orcid.org/0000-0002-6552-6703

Gustavo Henrique de Frias Castro

ORCID: https://orcid.org/0000-0002-5262-1445 Universidade Federal dos Vales do Jequitinhonha e Mucuri, Brazil

E-mail: gustavo.castro@ufvjm.edu.br

Roseli Aparecida dos Santos

ORCID: https://orcid.org/0000-0002-2724-1256

\begin{abstract}
Milk is rich in nutrients, but several factors in the production system interfere with its quality. The objective of this study was to analyze the composition and microbiological quality of raw milk stored in community tanks from the municipality of Aricanduva - Minas Gerais. Samples were collected from eight community tanks at different properties. The milk composition and temperature were analyzed using the digital milk analyzer. The total count of aerobic mesophilic microorganisms was performed at the Laboratory of Science and Technology of Products of Animal Origin, Department of Animal Science, Federal University of Vales do Jequitinhonha and Mucuri, Diamantina - Minas Gerais. The data obtained were compared to the values established by Normative Instruction (IN) $\mathrm{n}^{\circ} 76$, by means of Student's t-test and Wilcoxon's non-parametric test at the level of 5\% of significance. The average levels of fat $(3.55 \mathrm{~g} / 100 \mathrm{~g})$, protein $(3.00 \mathrm{~g} / 100 \mathrm{~g})$, lactose $(4.45 \mathrm{~g} / 100 \mathrm{~g})$ and total solids $(11.76 \mathrm{~g} / 100 \mathrm{~g})$ were within the standards minimum required. The content of defatted solids $(8.21 \mathrm{~g} / 100 \mathrm{~g})$ was the limiting factor to the compliance with IN76, with an average value lower than that established $(8.40 \mathrm{~g} / 100 \mathrm{~g})$. The temperature of the milk was higher than the standard required by the legislation and the count of mesophilic microorganisms did not differ from the legislation. It is concluded that the composition of raw milk stored in community tanks in the municipality of Aricanduva - Minas Gerais, compared to IN 76, did not fully met the legislation in all evaluated parameters.
\end{abstract}

Keywords: Legislation; Mesophiles; Temperature; Total solids.

\section{Resumo}

O leite é rico em nutrientes, porém vários fatores do sistema de produção interferem em sua qualidade. Objetivou-se analisar a composição e qualidade microbiológica do leite cru armazenado em tanques comunitários no município de 
Aricanduva MG. Foram coletadas amostras em duplicatas de oito tanques comunitários em diferentes propriedades. As análises de composição e temperatura do leite foram realizadas através do analisador de leite digital. A contagem total de microrganismos aeróbios mesófilos foi realizada no Laboratório de Ciência e Tecnologia de Produtos de Origem Animal do Departamento de Zootecnia, da Universidade Federal dos Vales do Jequitinhonha e Mucuri, Diamantina MG. Os dados obtidos foram contrastados aos valores estabelecidos pela Instrução Normativa (IN) $n^{\circ} 76$, por meio dos testes t de Student e Wilcoxon ao nível de 5\% de significância. Os teores médios de gordura (3,55 $\mathrm{g} / 100 \mathrm{~g})$, proteína $(3,00 \mathrm{~g} / 100 \mathrm{~g})$, lactose $(4,45 \mathrm{~g} / 100 \mathrm{~g})$ e sólidos totais $(11,76 \mathrm{~g} / 100 \mathrm{~g})$ encontraram-se dentro dos padrões mínimos exigidos. O teor de sólidos desengordurados $(8,21 \mathrm{~g} / 100 \mathrm{~g})$ foi o fator limitante ao atendimento à IN76, com valor médio menor que o estabelecido $(8,40 \mathrm{~g} / 100 \mathrm{~g})$. A temperatura do leite foi maior que o padrão exigido pela legislação e a contagem de microrganismos mesófilos não diferiu da legislação. Conclui-se que a composição do leite cru armazenado em tanques comunitários no município de Aricanduva MG, comparada à IN 76, não atendeu a legislação em todos os parâmetros avaliados e a sua qualidade microbiológica estava comprometida, uma vez que as temperaturas estavam acima do valor preconizado pela legislação.

Palavras-chave: Legislação; Mesófilos; Sólidos totais; Temperatura.

\section{Resumen}

La leche es rica en nutrientes, pero varios factores del sistema de producción interfieren con su calidad. El objetivo fue analizar la composición y calidad microbiológica de la leche cruda almacenada en tanques comunitarios en el municipio de Aricanduva MG. Se recolectaron muestras por duplicado de ocho tanques comunitarios en diferentes propiedades. Los análisis de composición y temperatura de la leche se realizaron utilizando un analizador de leche digital. El recuento total de microorganismos aeróbicos mesófilos se realizó en el Laboratorio de Ciencia y Tecnología de Productos de Origen Animal, Departamento de Ciencia Animal, Universidad Federal de Vales do Jequitinhonha y Mucuri, Diamantina MG. Los datos obtenidos se contrastaron con los valores establecidos por la Instrucción Normativa (IN) No. 76, utilizando las pruebas t de Student y Wilcoxon a un nivel de significancia del 5\%. Los contenidos medios de grasa (3,55 g / 100 g), proteína (3,00 g / $100 \mathrm{~g})$, lactosa (4,45 g / $100 \mathrm{~g})$ y sólidos totales $(11,76$ g / $100 \mathrm{~g})$ estuvieron dentro de los estándares mínimos requeridos. El contenido de sólidos desgrasados $(8.21 \mathrm{~g} / 100 \mathrm{~g})$ fue el factor limitante para cumplir con la IN76, con un valor promedio menor al establecido $(8.40 \mathrm{~g} \mathrm{/} \mathrm{100g).} \mathrm{La}$ temperatura de la leche fue más alta que el estándar requerido por la legislación y el recuento de microorganismos mesófilos no difirió de la legislación. Se concluye que la composición de la leche cruda almacenada en tanques comunitarios en el municipio de Aricanduva MG, en comparación con la EN 76, no cumplió con la legislación en todos los parámetros evaluados y su calidad microbiológica se vio comprometida, ya que las temperaturas estuvieron por encima del valor recomendado por legislación.

Palabras clave: Legislación; Mesófilos; Solidos totales; La temperatura.

\section{Introduction}

Cattle raising is one of the main activities in Brazil and it employs approximately 6.7 million people both directly and indirectly (Almeida et al., 2019). Dairy farming is expressive in Brazil. The country is ranked the fourth largest producer in the world (FAO, 2019). Among the Brazilian states, Minas Gerais stands out as the largest milk producer with 9,509,423.00 liters/year. This represents about $27.1 \%$ of the total production in Brazil, which is approximately 34.8 billion liters of milk (IBGE, 2019). Thus, milk plays an important social and economic role in the country.

Milk play an important role in human nutrition and is consumed at different stages of life, with nutritional relevance especially in childhood and old age. It is composed of water in addition to vitamins, minerals, proteins, fats, and carbohydrates that make up its the solid content (Elias et al., 2014). The fraction of each component of the solid part of milk (12 to 14\%) can represent from $3.5 \%$ to $4.5 \%$ for lipids, carbohydrates $4.6 \%$ to $5.2 \%$, proteins $3.2 \%$ to $3.5 \%$, and vitamins and minerals about $1 \%$. (Soares, 2013).

Milk must undergo strict quality control through the assessment of physicochemical and microbiological characteristics to be considered safe for human consumption and suitable for processing. It must comply with the standards required by law and be free of residues of any kind, adulterants, and preservatives. The Brazilian Normative Instruction (IN) 76 of the Ministry of Agriculture, Livestock and Supply covers the technical regulations for the identity and quality of refrigerated raw milk and pasteurized milk (Brazil, 2018). Considering the influence of temperature on microbial growth and, consequently, on the conservation of raw milk, IN 76 also establishes the mandatory cooling of milk. In addition, it should be 
transported in cooled bulk to preserve its quality until reception in establishments with official sanitary inspection (Brazil, 2018). Thus, the storage bulk tank, also known as an expansion or cooling tank, is a legal requirement.

Community bulk tanks are used by small milk producers, in which a single tank is acquired and shared by a group of producers. This allowed those who produce on a smaller scale and are unable to acquire and/or maintain a refrigeration tank to comply with the legislation. However, since the milk deposited in the tank comes from different farms, a series of factors related to the production system could interfere with the composition and microbiological quality of the milk in community tanks.

The objective of this study was to evaluate the composition and microbiological quality of raw milk refrigerated in community tanks in the city of Aricanduva - Minas Gerais compared to the values established by IN 76.

\section{Methodology}

The present study was carried out using a qualitative research methodology, both in the field and in the laboratory (Pereira et al., 2018).

\subsection{Characterizations of the Aricanduva-Minas Gerais microregion}

This work was carried out in Aricanduva, a municipality in the State of Minas Gerais located in the Alto Jequitinhonha region, micro-region of Capelinha (Figure 1), with a territorial unit area of $243,329 \mathrm{~km}^{2}$ and an estimated population of 5,269 inhabitants in 2020 (IBGE, 2020). The municipality's climate is tropical, classified as tropical climate with a winter dry season (Aw) according to Köppen and Geiger (1928), with an average temperature of $21.2{ }^{\circ} \mathrm{C}$ and an average annual rainfall of $1109 \mathrm{~mm}$ (Climate-data, 2020).

Figure 1 - Map of the Aricanduva microregion, Minas Gerais, Brazil.

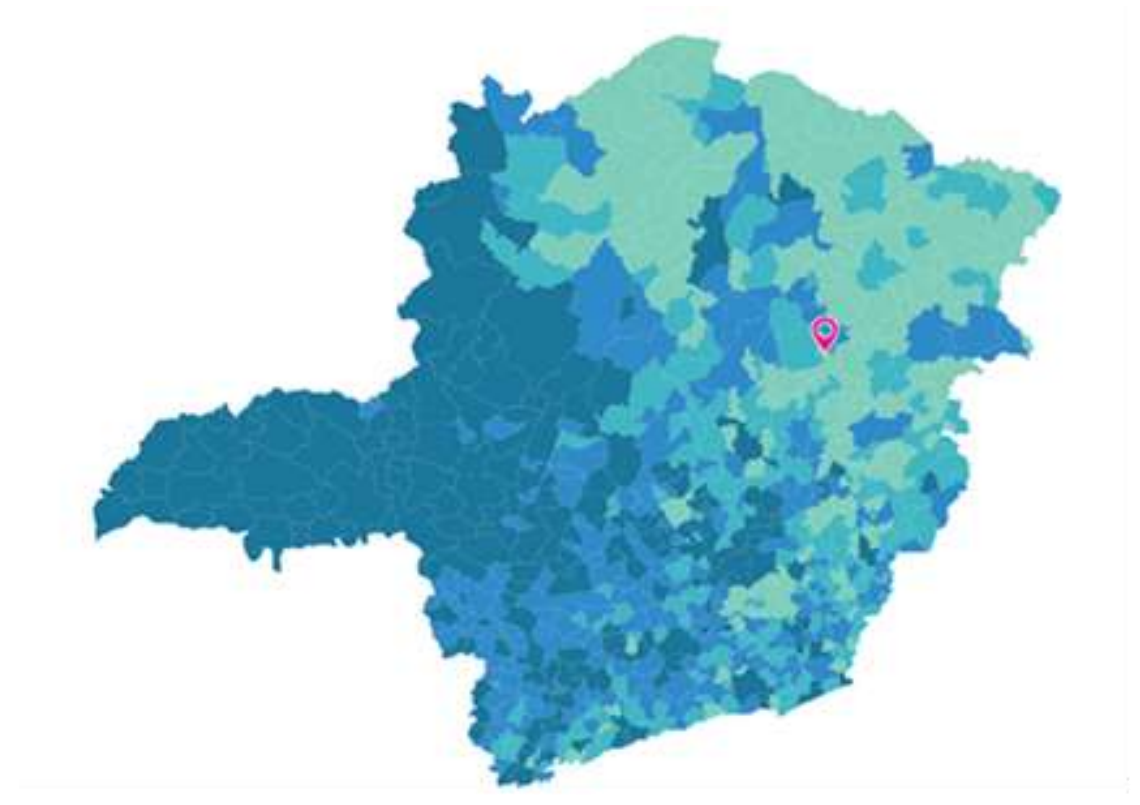

Source: IBGE (2020).

\subsection{Milk sampling in community tanks}

Samples of raw milk were collected in October 2017, from eight community tanks located in different properties in the municipality of Aricanduva - Minas Gerais. The number of producers using each tank ranged from two to eleven with an 
average of seven producers per tank. After homogenization of the milk (performed by mechanisms of the tank itself), the milk samples were collected with the aid of a stainless steel shell that was washed with water and neutral detergent and dried before collection.

Milk samples were collected in duplicates, on the first day of storage, after all producers had already deposited their milk in the tank. In addition, the refrigeration temperature data presented on the panel of each tank and the milk temperature of each sample was recorded using the digital milk analyzer (Vicente et al., 2020).

\subsection{Milk composition analysis}

Composition analyzes, g/100g, of fat, protein, lactose, total solids and defatted solids were performed immediately after collection, using a digital milk analyzer (Vicente et al., 2020).

\subsection{Microbiological analysis}

For the total count of aerobic mesophilic microorganisms, the milk samples were placed in coolers using sterilized bottles containing Bronopol preservative (2-Bromo-2-nitropropane-1,3-diol), and sent to the Laboratory of Science and Technology of Products of Animal Origin (CTPOA) of the Animal Science Department, Federal University of Jequitinhonha and Mucuri Valleys (UFVJM) in Diamantina MG, $250 \mathrm{~km}$ away from the collection sites.

Prior to the microbiological analysis, the milk samples were homogenized by inversion and $10 \mathrm{~mL}$ aliquots were collected for the preparation of serial decimal dilutions (up to 10-4) in saline medium ( $\mathrm{NaCl}$ ) at $0.85 \%$, homogenized and then submitted to analyzes (Silva et al., 2017). The total count of aerobic mesophilic microorganisms was made by inoculating aliquots of appropriate decimal dilutions on Petri dishes containing standard agar for counting (HIMEDIA - India) and incubated at $35^{\circ} \mathrm{C}$ for 48 hours. After counting the colonies, the results were presented in colony forming units $(\mathrm{CFU} / \mathrm{mL}$ of raw milk), according to Silva et al. (2017).

\subsection{Statistical analysis}

Statistical analyzes were conducted using the R program (2019, version 3.5.3 "Great Truth"), adopting a 5\% significance level. From the duplicate observations, one observation was obtained for each $\operatorname{tank}(n=8)$. For variables that had a normal distribution according to the Shapiro-Wilk test $(\mathrm{P}<0.05)$, the Student $\mathrm{t}$ test was used to compare the sample means with the values established by the IN 76. For variables that were not normally distributed, the non-parametric Wilcoxon test was used.

\section{Results and Discussion}

\subsection{Composition of milk in community tanks}

Table 1 shows the averages of the composition parameters (fat, protein, lactose, total solids, and defatted solids) of raw milk from community tanks in the municipality of Aricanduva - Minas Gerais, compared with the values established by IN 76 (Brazil, 2018). 
Table 1 - Means and respective standard deviations of the composition parameters of raw milk from community tanks in the municipality of Aricanduva MG, compared with the values established by IN 76 (Brazil, 2018).

\begin{tabular}{cccc}
\hline $\begin{array}{c}\text { Composition } \\
\text { Parameters (g/100g) }\end{array}$ & IN 76 & $\begin{array}{c}\text { Samples } \\
\text { Standard Deviation) }\end{array}$ & P-value \\
\hline Fat & 3.00 & $3.55 \pm 0.28$ & $<0.001$ \\
Protein & 2.90 & $3.00 \pm 0.05$ & $<0.001$ \\
Lactose & 4.30 & $4.45 \pm 0.08$ & $<0.001$ \\
Total solids & 11.40 & $11.76 \pm 0.33$ & 0.008 \\
Degreased solids & 8.40 & $8.21 \pm 0.14$ & 0.003 \\
\hline
\end{tabular}

Source: Authors (based on research data).

We observed that the average levels of fat, protein, lactose, and total solids met the minimum standards required by IN 76 (Table 1). In addition, their average values were above those established by the legislation. This would be beneficial to dairy organizations, enabling greater profitability, since high solids content would increase the yield in the transformation of milk into dairy products (Gonçalves et al., 2020). The average content of total solids found, corroborates the average of producer four $(11.84 \mathrm{~g} / 100 \mathrm{~g})$ in the work by Guimarães et al. (2020) who evaluated the quality of refrigerated fresh milk from four rural properties in the municipality of Rio Verde - GO.

The results of the present work corroborate with the characteristic of the dairy farms in the studied city. They are characterized by extensive breeding systems, with milking alternating between manual and mechanical, and pasture being the main source of food with crossbred Zebu animals. Thus, producers in the region choose to manage more rustic cattle, which adapt better to the climate and relief conditions of the region but produce a smaller volume of milk (average production around $100 \mathrm{~kg}$ of milk/day/property) but, with high solids content.

The high average fat content in the milk can be explained by the season in which samples were collected. Samples were obtained during the transition from the dry to the rainy season, when forages usually have a high fiber content, which may have influenced the fat content in milk (Santos, Neto, Bezerra \& Medeiros, 2020). Fukumoto et al. (2010) mentioned significant changes in the fat content of milk at different times of the year, which were justified by changes in pasture quality and in the feed provided to the animals.

The average protein content met the minimum required by IN 76. This result may be related to the concentrate supplementation offered by producers to animals under grazing conditions during the dry season. Doran et al. (2021) demonstrated that dairy cows receiving concentrate supplementation under grazing conditions increased the concentration of protein in milk. The defatted solids content, which represents the constituents of milk minus water and fat (Dias \& Ant, 2014), in this study $(8.21 \mathrm{~g} / 100 \mathrm{~g})$ was lower than that established by IN $76(8.40 \mathrm{~g} / 100 \mathrm{~g})$. This result could indicate a probable decrease in the average lactose and protein content, but the sample averages of these components were in accordance with legislation.

Lactose had a low standard deviation $( \pm 0.08)$ and it was the one with the least variation among the studied parameters. The average lactose content found in this study was similar to that found by Guimarães et al. (2020) which ranged from $4.19 \mathrm{~g} / 100 \mathrm{~g}$ to $4.50 \mathrm{~g} / 100 \mathrm{~g}$. Lactose is one of the most stable components of milk, being related to the regulation of osmotic pressure in the mammary gland. By attracting water into the alveoli, it consequently reduces the concentration of other components such as fat (Peruzzi, Monreal, Caramalac \& Caramalac, 2016). Therefore, in rare situations there will be changes in the lactose content in milk. 


\subsection{Temperature and microbiological quality of milk in community tanks}

The results for the parameters temperature of the milk sample, milk temperature marked on the tank panel, and count of evaluated microorganisms are shown in Table 2.

Table 2 - Temperature of the milk sample, temperature indicated in the tank and total count of aerobic mesophilic microorganisms in raw milk, stored in community tanks in the municipality of Aricanduva MG, compared with the values established by IN 76 (Brazil, 2018).

\begin{tabular}{cccc}
\hline Variable & IN 76 & $\begin{array}{c}\text { Samples } \\
\text { (Average } \pm \text { Standard Deviation) }\end{array}$ & P-value \\
\hline Milk sample temperature $\left({ }^{\circ} \mathrm{C}\right)$ & 4 & $10.31 \pm 9.47$ & 0.004 \\
Temperature marked on the tank panel $\left({ }^{\circ} \mathrm{C}\right)$ & 4 & $8.96 \pm 8.79$ & 0.02 \\
Colony forming units $(\mathrm{UFCx} 105 / \mathrm{mL})$ & 3 & $7.45 \pm 9.41$ & 0.32 \\
\hline
\end{tabular}

Source: Authors (based on research data).

Milk storage temperature was significantly higher $(\mathrm{P}<0$.05) than the value recommended by the legislation. Hot milks from different properties are transported in cans, arrive at the tank at different times, and are mixed with already refrigerated milk (Pereira \& Magalhães, 2012). This procedure contributes to slower refrigeration of stored milk, which can lead to loss of quality and even refusal by the processing industry. This may explain the higher temperature found in this study (Table 2), considering that the collection was made in the morning, right after the milk was deposited by all registered producers in the sampled tanks.

Microbiological contamination of milk can occur during and after milking and the multiplication of microorganisms can be accentuated if cooling during storage is not appropriate. The cooling of milk following milking at a temperature below $4^{\circ} \mathrm{C}$ (Sidney, Thomas \& Dhasan, 2020), in cooling tanks and under adequate hygiene conditions, is undoubtedly one of the main points when it comes to microbiological quality. In addition, higher bacterial counts are observed in tanks with higher storage temperature (Gonzalo, Juárez, García-Jimeno \& De La Fuente, 2019) and, due to its nutritional richness, milk becomes an important culture medium, enabling the rapid development of different types of microorganisms, such as mesophilic aerobic bacteria.

Aerobic mesophilic bacteria are those capable of growing at temperatures from 20 to $40^{\circ} \mathrm{C}$ and indicate the quality of the food. These microorganisms predominate in situations where there is a lack of basic hygiene conditions, as well as lack of milk refrigeration (Costa et al., 2020). As they multiply, aerobic mesophilic bacteria promote chemical changes in the product, such as fermenting lactose and producing lactic acid, causing acidification of the milk and compromising its use by the industry (Fonseca, 2000). This microorganism is an indicator of the hygiene conditions in which milk is obtained, both in terms of the quality of the water used to clean milking equipment, and in terms of hygiene practices during milking. Although no statistically significant difference $(\mathrm{P}>0.05)$ was observed in this study between the count of mesophilic microorganisms in the samples compared to the permissible limit according to IN 76, it is interesting to note that the variation was high for this parameter (Table 2).

In this sense, it was observed that, if on the one hand the community tanks facilitate compliance with the legislation by the small producer, on the other hand they can present problems in the management of the microbiological quality of the milk. Given that many populations of microorganisms continue their development until the temperature reaches $4^{\circ} \mathrm{C}$, there may be losses due to acidification by mesophilic bacteria (Santos et al., 2020) and loss of casein stability (Horne, 2020). Temperature interferes with proteolysis and lipolysis, since plasmin and lipoprotein lipase, which are the main enzymes participating in these processes, are activated when the milk is subjected to inadequate refrigeration temperature, causing high 
degradation of milk proteins, especially casein, and triglycerides (Ma, Barbano \& Santos, 2003).

Cooling milk can mitigate or inhibit microbial growth. However, it does not ensure the microbiological quality of the milk by itself. Allied to this, awareness-raising activities should be carried out regarding good sanitary practices in handling and milking, in order to obtain product of good microbiological quality (Neta et al., 2018). In general, on farms that receive technical assistance, the count of microorganisms tends to be lower (Luz, Bicalho, Oliveira \& Simões, 2011). It is essential to provide technical education and training to family farms, which is the case of most milk producers who use community tanks. Actions regarding the practices of obtaining milk with hygiene, cleaning of milking equipment and the importance of refrigeration of milk, will contribute to the development of dairy farming, in addition to ensuring the food safety of society.

\section{Conclusion}

It is concluded that the composition of milk and quality of raw milk stored in community tanks in the municipality of Aricanduva - Minas Gerais, showed average levels of fat, protein, total solid lactose, and mesophilic microorganisms count within the limits established by IN 76. However, the content of degreased solids and temperatures, did not meet what is stablished by the legislation, being the limiting factors for full compliance with IN 76. In this sense, for further inferences, further studies are needed on the composition and microbiological quality of refrigerated raw milk in these community tanks.

\section{Credit authorship contribution statement}

Cassiane Gomes dos Santos: Conceptualization, Investigation, Project administration, Resources, Writing - Original Draft, Writing - Review \& Editing. Gabriel Machado Dallago: Conceptualization, Formal analysis, Writing - Original Draft, Writing - Review \& Editing. Mariana Almeida Dumont: Resources, Writing - Review \& Editing. Leandro Vitor de Figueiredo: Resources, Writing - Review \& Editing. Marcela Ramos Duarte: Writing - Review \& Editing. Cleube Andrade Boari: Resources, Writing - Review \& Editing. Gustavo Henrique de Frias Castro: Resources, Writing - Review \& Editing. Roseli Aparecida dos Santos: Conceptualization, Project administration, Resources, Supervision, Writing - Original Draft, Writing Review \& Editing.

\section{References}

Almeida, J. V., Francischini, R., da Silva, F. F., \& Bett, V. (2019). Rastreabilidade na bovinocultura brasileira: condições e benefícios. PUBVET, 13, 130.

Brasil (2018). Ministério da Agricultura, Pecuária e Abastecimento. Instrução Normativa n. 76, de 26 de novembro de 2018. Diário Oficial da União. Regulamentos Técnicos que fixam a identidade e as características de qualidade que devem apresentar o leite cru refrigerado, o leite pasteurizado e o leite pasteurizado tipo A. http://www.in.gov.br/materia/-/asset_publisher/Kujrw0TZC2Mb/content/id/52750137/do1- 2018-11-30-instrucao-normativa-n-76-de-26de-novembro-de-2018-52749894IN\%2076.

Costa, C. A. C. B., dos Santos, J. V. L., de Melo, É. A. P., de Freitas, A. J. D., dos Santos Sousa, J., de Freitas, J. M. D., \& de Freitas, J. D. (2020). Caracterização da qualidade microbiológica do leite cru comercializado informalmente na cidade de Murici, Alagoas/Characterization of the microbiological quality of raw milk informally marketed in the city of Murici, Alagoas. Brazilian Journal of Development, 6(2), 7026-7035.

Dados climáticos para cidades mundiais. https://pt.climate-data.org/

Dias, J. A., \& Antes, F. G. (2014). Qualidade físico-química, higiênico-sanitária e composicional do leite cru: indicadores e aplicações práticas da Instrução Normativa 62. Embrapa Rondônia-Documentos (INFOTECA-E).

Doran, M. J., Mulligan, F. J., Lynch, M. B., O'Sullivan, M., Fahey, A. G., McKay, Z. C. \& Pierce, K. M. (2021). Effects of genotype and concentrate supplementation on milk composition and selected milk processability parameters in late-lactation spring-calving grazing dairy cows. International Dairy Journal, 114, 104942.

Elias, T., Silva, A., \& Júnior, H. (2014). Modelo não linear para a relação entre proteína e extrato seco desengordurado do leite (pp. 629-633). Revista da Estatística da Universidade Federal de Ouro Preto, 3(3).

Food and Agriculture Organization of the United Nations (FAO). http://www.fao.org/home/en/

Fonseca, L. F. L. (2000). Qualidade do leite e controle de mastite. Lemos Editorial, 2000 il... 
Fukumoto, N. M., Damasceno, J. C., Deresz, F., Martins, C. E., Cóser, A. C., \& Santos, G. T. D. (2010). Produção e composição do leite, consumo de matéria seca e taxa de lotação em pastagens de gramíneas tropicais manejadas sob lotação rotacionada. Revista Brasileira de Zootecnia, 39(7), $1548-1557$.

Gonçalves, R. B. O., Barbosa, K. F. D., Areco, A. E. T., Ferreira, E. M., Costa, L. E. P., Guimarães, L. D. C. R., \& de Souza Faria, A. L. B. (2020). Características microbiológicas, celulares, físicas e químicas de leite cru refrigerado em Aparecida do Taboado-MS/Microbiological, cellular, physical and chemical characteristics of refrigerated raw milk in Apareceda Do Taboado-MS. Brazilian Journal of Development, 6(2), 7290-7300.

Gonzalo, C., Juárez, M. T., García-Jimeno, M. C., \& De La Fuente, L. F. (2019). Bulk tank somatic cell count and total bacterial count are affected by target practices and milking machine features in dairy sheep flocks in Castilla y León region, Spain. Small Ruminant Research, 178, $22-29$.

Guimarães, G. M., Mateus, L. S., Moraes, A. I. P., da Costa, W. S., Soares, N. R., dos Santos, L. S., \& dos Santos, P. A. (2020). Qualidade do leite in natura perante a instrução normativa IN 76 do Ministério da Agricultura, Pecuária e Abastecimento do Brasil. Research, Society and Development, 9(9), e262996746e262996746.

Horne, D. S. (2020). Casein micelle structure and stability. In Milk proteins (pp. 213-250). Academic Press.

Instituto Brasileiro de Geografia e Estatística (IBGE). https://www.ibge.gov.br/

Luz, D. F., Bicalho, F. A., de Oliveira, M. V. M., \& Simões, A. R. P. (2011). Avaliação microbiológica em leite pasteurizado e cru refrigerado de produtores da região do Alto Pantanal Sul-Mato-Grossense. Agrarian, 4(14), 367-374.

Ma, Y., Barbano, D. M., \& Santos, M. (2003). Effect of CO2 addition to raw milk on proteolysis and lipolysis at 4 C. Journal of Dairy Science, 86(5), 16161631 .

Neta, I. B. P., da Silva, A. R., do Carmo Santos, G. M., Athiê, T. S., Reis, W. C. S., \& Seixas, V. N. C. (2018). Aplicação das boas práticas agrícolas na produção de leite. PUBVET, 12, 172.

Pereira, A. S., Shitsuka, D. M., Parreira, F. J., \& Shitsuka, R. (2018). Metodologia da pesquisa científica. UFSM.

Pereira, D. A., \& Magalhães, F. A. R. (2012). Fatores Impactantes Na Qualidade Do Leite De Tanques Comunitários Na Microrregião De Juiz De Fora (MG). Revista do Instituto de Laticínios Cândido Tostes, 67(385), 74.

Peruzzi, A. Z., Monreal, A. C. D., Caramalac, S. M., \& Caramalac, S. M. (2016). Avaliação da produção leiteira e análise centesimal do leite de ovelhas da raça Santa Inês. Agrarian, 9(32), 182-191.

Santos, D. B., Aguiar, R. O., da Cruz, W. P., da Silva Bernardino, P. D. L., da Silva Martins, L. H., Carvalho, F. I. M., \& Silva, P. A. (2020). Desenvolvimento e caracterização de doces de leite bubalino pastosos saborizados com doces de bacuri e Cupuaçu. Brazilian Journal of Development, 6 (8), 56917-56935.

Santos, G. C. L., Neto, S. G., Bezerra, L. R., \& de Medeiros, A. N. (2020). Uso de tortas na alimentação de vacas leiteiras: uma revisão/Use of cakes to feed dairy cows: a review. Brazilian Journal of Animal and Environmental Research, 3(1), 89-113.

Sidney, S., Thomas, J., \& Dhasan, M. L. (2020). A standalone PV operated DC milk chiller for Indian climate zones. Sādhanā, 45(1), 1-11.

Silva, N., Junqueira, V. C. A., de Arruda Silveira, N. F., Taniwaki, M. H., Gomes, R. A. R., \& Okazaki, M. M. (2017). Manual de métodos de análise microbiológica de alimentos e água. Editora Blucher.

Soares, F. A. C. (2013). Composição do leite: fatores que alteram a qualidade química. Porto Alegre: Universidade Federal do Rio Grande do Sul.

Vicente, S. L. A., Nogueira, D. M., Voltolini, T. V., Yamamoto, S. M., Lopes Júnior, E. S., \& Moraes, S. A. (2020). Avaliação on-farm dos níveis de energia na dieta sobre a produção e a composição físico-química de leite de cabras. Arquivo Brasileiro de Medicina Veterinária e Zootecnia, 72(4), $1424-1432$. 